\title{
Living the Vision: A Disadvantaged and Marginalized Alternative School's Perspective on School Culture and Educational Change
}

\author{
Sunnie Lee Watson ${ }^{1, *} \&$ Charles M. Reigeluth ${ }^{2}$ \\ ${ }^{1}$ Department of Curriculum and Instruction, College of Education, Purdue University, West \\ Lafayette, IN, USA \\ ${ }^{2}$ Department of Instructional Systems Technology, School of Education, Indiana University, \\ USA \\ *Corresponding author: Department of Curriculum and Instruction, College of Education, \\ Purdue University, Office: BRNG 3126 Purdue University, West Lafayette, IN, USA \\ Tel: 1-765-494-6056_E-mail: watson82@purdue.edu
}

Received: February 12, 2013 Accepted: April 22, $2013 \quad$ Published: April 30, 2013

doi:10.5296/ije.v5i2.3256 URL: http://dx.doi.org/10.5296/ije.v5i2.3256

\begin{abstract}
The United States' educational system have responded to school reform needs over the last several decades, but had little success in producing meaningful change. In this paper, we argue that there is a need to engage in a more inclusive social discourse to address the problems in the educational system in the United States. This two year critical ethnographic study examines a disadvantaged alternative school and it's members' perspectives on school culture and school change. Through a discussion about the district-wide, systemic change effort that has been implemented in their school district, participants share perspectives on what schools can do in order to meet disadvantaged and marginalized students' needs. Through a process of listening to the voices of these marginalized and disadvantaged students, we hope to enrich the discussion of educational change.
\end{abstract}

Keywords: at-risk students; disadvantaged students; school culture; systemic change; school reform 


\section{Introduction}

Disadvantaged students in schools bring very different sets of family and community cultures into the learning communities (Brown \& Gilligan, 1992; Lareau \& Horvat, 1999; Willis, 1981). Research shows that classroom learning is reflexive and interactive and that language in the classroom draws heavily from the sociolinguistic experiences of students at home (Bernstein 1975; Mehan \& Griffin, 1980). Also studies of the curriculum, the hidden curriculum, and the relationships between teachers and students have revealed how schooling can contribute to social reproduction (Anyon, 1981; Apple, 1979; Wilcox, 1982). So the cultures of learning established by these student bodies and their teachers are very different from the mainstream learning communities within a school district. Policies and practices in schools tend to group and isolate these student bodies to gain convenience in administration and instruction, and little consideration is given to whether, for the students, the experience of being grouped and isolated from the larger learning community is positive or negative.

School change for higher standards in the absence of fundamental changes that are needed to address the critical needs of diverse students only increases drop-out rates for those students who can scarcely meet current standards. It is clear that there is an urgent need for school change for the educational system as a whole, which are attuned to the needs of the disadvantaged and address those issues with special consideration.

This study examines to what degree a disadvantaged student population is included in a systemic change effort by examining a marginalized learning communities' culture of learning and its role within a systemic educational change process. This study provides tentative improvement recommendations for educational change efforts in school districts that 1) seek to effectively teach and support disadvantaged and marginalized learning communities and student bodies, and 2) are replicating existing conditions by not actively involving disadvantaged and marginalized learning communities in educational change processes.

\section{Background Literature}

\subsection{Systemic Educational Change}

Among recent educational change movements in the US, systemic school change or systemic educational change is a movement that strives to change school culture so that schools meet all learners' needs, rather than only the majority of learners' needs. Scholars of systemic school change movements argue that the current factory-model, industrial-age, school system is not designed to meet individual learner needs. Systemic educational change seeks to shift from a paradigm in which time is held constant, thereby forcing achievement to vary, which is a sorting-based paradigm, to a paradigm designed specifically to meet the needs of learners by allowing students as much time as each needs to reach proficiency and to move on as soon as each is ready (McCombs \& Whisler, 1997; Reigeluth, 1999; Senge et al., 2000; Tomlinson, 2003). 
Systemic educational change applies soft systems theory in the works of educational systems. For example, Banathy (1991) examines educational systems through three lenses: a "still picture lens" to appreciate the components comprising the system and their relationships, a "motion picture lens" to recognize the processes and dynamics of the system, and a "bird's eye view lens" to be aware of the relationships between the system, its peer systems and suprasystems. Senge (1990) applies systems theory specifically to organizational learning, stating that the organization can learn to work as an interrelated, holistic learning community, rather than functioning as isolated departments.

As a relatively new movement in school change, several systemic educational change efforts have been implemented. Examples of these efforts are based on the following work: Jenlink, Reigeluth, Carr, and Nelson's (1998) Guidance System for Transforming Education, Duffy's Step-Up-To-Excellence (2002), Schlechty's (2002) guidelines for leadership in school reform, Hammer and Champy's (1993; 2003) Business Process Redesign/Reengineering, and Ackoff's (1981) Idealized Systems Design.

One of the best practices of systemic change is the change effort the Chugach School District (CSD) has carried out. The 200 students in CSD are scattered throughout 22,000 square miles of remote area in South-central Alaska. The district was in crisis twelve years ago due to low student reading ability, and the school district committed to a systemic change effort. Battino and Clem (2006) explain how the CSD's use of individual learning plans, student assessment binders, student learning profiles, and student life-skills portfolios support and document progress toward mastery in all standards for each learner. The students are given the flexibility to achieve levels at their own pace, not having to wait for the rest of the class or being pushed into learning beyond their developmental level. Graduation requirements exceed state requirements, as students are allowed extra time to achieve that level if necessary, but must meet the high rigor of graduation level. Student accomplishment in academic performance increased dramatically as a result of these systemic changes (Battino \& Clem, 2006).

Caine (2006) also found strong positive changes through systemic educational change in their extensive engagement on a project called "Learning to Learn" in Adelaide, South Australia, an initiative of the government that covered a network of over 170 educational sites. From preschool to $12^{\text {th }}$ grade, brain-based, learner-centered learning environments are combined with a larger set of systemic changes, leading to both better student achievement and significant changes in the culture and operation of the system itself. While these schools have been successful partially because of the smaller scale of the districts and schools when compared to others, the vision and process of school transformation that systemic change efforts provide appear to be promising.

\subsection{Disadvantaged Students in Systemic Educational Change}

Despite the potential for successes and even with systemic change processes taking account of disadvantaged students' position in the transformation in a much more inclusive way than other school reforms, systemic change processes have not been able involved disadvantaged 
student bodies and communities as active agents in the change processes. As in most school activities and change efforts, disadvantaged student groups are typically isolated, either physically, psychologically or both, from the rest of the learning community, and it can be difficult for their voices to be represented and their needs recognized in a change effort that involves the larger learning community.

Disadvantaged students are students who are in "in danger of failing at school, or in making a successful transition to work. Educational, social and vocational failure are predicted by a range of factors, including poverty, ethnic status, family circumstances, language, type of school, geography and community" (Day, Veen \& Walraven, 1997, p. 17). Literature identifies various reasons for disadvantage in education, such as growing up in poverty or low social class; being born with too many siblings; growing up with unemployed parents; having a teenager, illiterate, or impaired parent; and growing up in a community of high social disorganization (Schorr \& Schorr,1988). School risk factors such as learners' attitudes and motivation levels, low teacher expectations, poor standards in planning of teaching, poor assessment of learning, and the prevalent anti-school culture and peer-group attitudes towards schooling are also identified as major obstacles to educational success for these students (Cox, 2000; Hargis, 2006).

Currently, very little research exists on disadvantaged and marginalized students' roles in, or perspectives on, systemic educational change for improvement in school culture. And although a small number of change researchers have disadvantaged populations in educational system, they have often been viewed as objects of research rather than resources of new ideas or visions for educational change (Carr-Chellman, Beabout, Almeida \& Gursoy, 2009).

Being disadvantaged is not only a relative state, but also a normative one as in "to be unfairly treated relative to others" (Fincher \& Saunders, 2001, p. 8), as it refers to disadvantaging processes that cause the production and reproduction of disadvantage for people and places (Snyder, Angus \& Sutherland-Smith, 2002). As a part of these disadvantaging processes, these disadvantaged students are rarely included in the design and improvement of educational systems.

Based on theoretical frameworks that address social inequity and the importance of social discourse (Cohen \& Fung, 2004; Giroux, 1991, Furman, 2004), we argue that listening to the voices of marginalized and disadvantaged student populations is critical. In addition, Flood and Jackson (1991) explain systems thinking in the light of critique, emancipation, and pluralism when considering systems wherein inequality of power exists in relation to opportunity, authority, and control. Drawing from this Critical Systems Theory framework, we are called to engage in user-design by embracing as many different populations as possible in educational change (Carr-Chellman et al., 2009). Therefore, this study seeks to listen to disadvantaged students who are frequently overlooked in the process of applying the theoretical framework of idealized systems design and systemic change for schools. We believe that it will contribute to expanding the discussion of school change to become more inclusive, and therefore ultimately change efforts will be able to take these important voices 
into account in creating more effective and successful schools.

\section{Research Questions}

The following questions guided the study:

1) From disadvantaged students' perspective, what kind of school culture is needed?

2) From disadvantaged students' perspective, how can educational systems be improved?

3) How are members of the alternative school involved in the district-wide systemic change effort?

4) How can systemic change efforts be improved to better represent disadvantaged students?

\section{Methods}

\subsection{Research Design}

The researchers chose a critical ethnographic methodology for this study of the disadvantaged alternative school and its perspectives on a district-wide systemic change effort. The application of critical ethnographic methodology allowed us to strive to illuminate the nature of culture and human agency at a more comprehensive level (Carspecken, 1996).

As a main medium through which critical ethnographic methods are applied, we were consciously engaged in a hermeneutic circle (Habermas, 1987), in order to comprehend meanings of school culture and systemic educational change, as the participants themselves understood it. The hermeneutic circle was applied to gain as much insider perspectives as possible, and peer debriefing and member checking methods were also used to further confirm this goal (Carspecken, 1996).

As the purpose of the study was to understand how disadvantaged students were included in a systemic educational change effort and what their perspectives were on school improvement, critical perspectives were brought to the current educational system, as well as the perspective on the need for a paradigm change for the successful learning of all students, including disadvantaged students.

\subsection{Site Description}

The study took place during at the Enrichment Institute (EI), an alternative high school in a small Mid-western metropolitan school district in the United States. At the time of the study, the entire school district served approximately 5,600 students. The student population was predominantly white with less than $18 \%$ minority students, and $52 \%$ of students received free or reduced lunch and textbooks, eclipsing the state average (Indiana Department of Education, 2010). 
The school district was involved in a district wide systemic change effort, called "Path to Success", in order to move towards an information age school system that meets the needs of the district's students through a learner-centered paradigm of education. The district was collaborating with facilitators at Midwest University. A professor at Midwest University who conducted research in systemic change agreed to serve as facilitator, along with a team of doctoral students, after being invited by leaders of all the major stakeholder groups identified in the district. The effort was a district-wide ecological systemic transformation (Squire \& Reigeluth, 2000) that was following the guidelines of the Guidance System for Transforming Education (GSTE), which provides a school transformation guide for transforming schools into learner-centered, information age schools (Reigeluth, 1994).

Table 1: Revised discrete events in the GSTE

\begin{tabular}{|c|c|}
\hline Phase I. Initiate a & Facilitators assess and enhance their own readiness for the process and form a Support \\
\hline Systemic Change & Team. \\
\hline \multirow[t]{4}{*}{ Effort } & Facilitators establish or redefine a relationship with a school district and discuss per diem \\
\hline & payment for Event 3. \\
\hline & Facilitators assess and enhance district readiness for change. \\
\hline & Negotiate and sign a contract/agreement with the superintendent and board for Phase II. \\
\hline Phase II. & Facilitators and superintendent form the Starter Team. \\
\hline Develop Starter & Hold a retreat to develop the Starter Team dynamic. \\
\hline \multirow[t]{7}{*}{ Team } & Develop Starter Team understanding of systems, design, mental models, the systemic \\
\hline & change process, dialogue, and small-group facilitation. \\
\hline & Assess and enhance district and community capacity for change. (Identify assets and \\
\hline & barriers, and use community forums if needed.) \\
\hline & Develop an agreement/contract with the Starter Team and School Board for Phase III, scope \\
\hline & out resource needs, and plan a budget for internal funding and a proposal for external \\
\hline & funding. \\
\hline
\end{tabular}

\begin{tabular}{ll}
\hline Phase III. & Starter Team expands into the Leadership Team, Starter Team becomes facilitators, \\
Develop the & facilitator becomes an advisor and "critical friend." \\
District-Wide & Hold a one-day retreat to develop the Leadership Team dynamic. \\
Framework and & Facilitators develop Leadership Team understanding of systems, design, mental models, the \\
Capacity for & systemic change process, dialogue, and small-group facilitation. (Address throughout \\
Change & Events 13-17.) \\
& Leadership Team develops a district-wide framework with broad stakeholder participation \\
& (community forums). This includes identifying changes in the community's educational \\
& needs, and using them to develop a mission, vision, and core values for an ideal school \\
& system. It takes this opportunity to assess and enhance district and community interest in, \\
& and culture for, systemic change. It develops pyramid groups for broad stakeholder \\
& involvement. \\
& Leadership Team identifies current and recent change efforts and decides what relation \\
& those should have with this effort.
\end{tabular}


Leadership Team develops a change process strategy, including capacity building and funding. Advisor's role is defined and funded for Phase IV.

\begin{tabular}{|c|c|}
\hline $\begin{array}{l}\text { Phase IV. Create } \\
\text { Ideal Designs for } \\
\text { a New } \\
\text { Educational } \\
\text { System }\end{array}$ & $\begin{array}{l}\text { Leadership Team forms and capacitates building-level Design Teams and conducts a } \\
\text { workshop on the framework. } \\
\text { Design Teams create building-level designs and systems for evaluating those designs with } \\
\text { broad stakeholder involvement. Leadership Team supports and monitors the Design } \\
\text { Teams. } \\
\text { Leadership Team forms and capacitates a district-level Design Team. } \\
\text { Design Team creates a design for ideal district administrative and governance systems, and } \\
\text { systems for evaluating that design, with broad stakeholder involvement. Leadership Team } \\
\text { supports and monitors this Design Team. }\end{array}$ \\
\hline $\begin{array}{l}\text { Phase V. } \\
\text { Implement and } \\
\text { Evolve the New } \\
\text { Educational } \\
\text { System }\end{array}$ & $\begin{array}{l}\text { Design teams create building-level processes for evolving as close as possible to their } \\
\text { ideal designs. Leadership Team supports and monitors the design teams. } \\
\text { Carry out implementation plans, formative evaluations, and revisions of the evolving } \\
\text { designs and the implementation processes. } \\
\text { Periodically evolve the ideal designs (building-level and district-level). }\end{array}$ \\
\hline
\end{tabular}

Note. From "Trends and issues in p-12 educational change" by C. M. Reigeluth \& F. M. Duffy, 2007 In R. A. Reiser \& J. V. Dempsey (Eds.), Trends and Issues in Instructional Design and Technology (Second ed.). Upper Saddle River, New Jersey: Pearson, Merris Prentice Hall.

The following was the 'Vision Mission Statement' of the Path to Success, which was posted in every classroom in the district:

MSD of Mid-western Township is an information-age school corporation commit- ted to being learner centered. A focus on learning and continuous personal growth is promoted in a safe, respectful and caring environment characterized by high expectations. Learning Communities are the means to fostering collaboration and empowerment. Assessments, interventions and accommodations are used to meet the academic, social, emotional, physical, and developmental needs of all learners.

This school district had one high school, one middle school, two intermediate schools, four elementary schools and finally, an alternative school, which this study was conducted at. Founded about five years prior to this study, the alternative school, the Enrichment Institute, was a physically isolated alternative school that in principle was a part of the Central High School. While this alternative school was originally established for students who preferred flexible learning environments and project-based learning, it had come to only serve disadvantaged and at-risk students who were expelled from the high school. These students were clearly failing at school, mostly because of disadvantaged factors, such as, not having enough family support to go to school, or having gotten in trouble with the law, drugs, pregnancy, or extreme behavioral problems at school. The EI was located about a mile south 
of the high school grounds, and the students were not allowed to go on the high school grounds or the adjacent district library, or the police would arrest them.

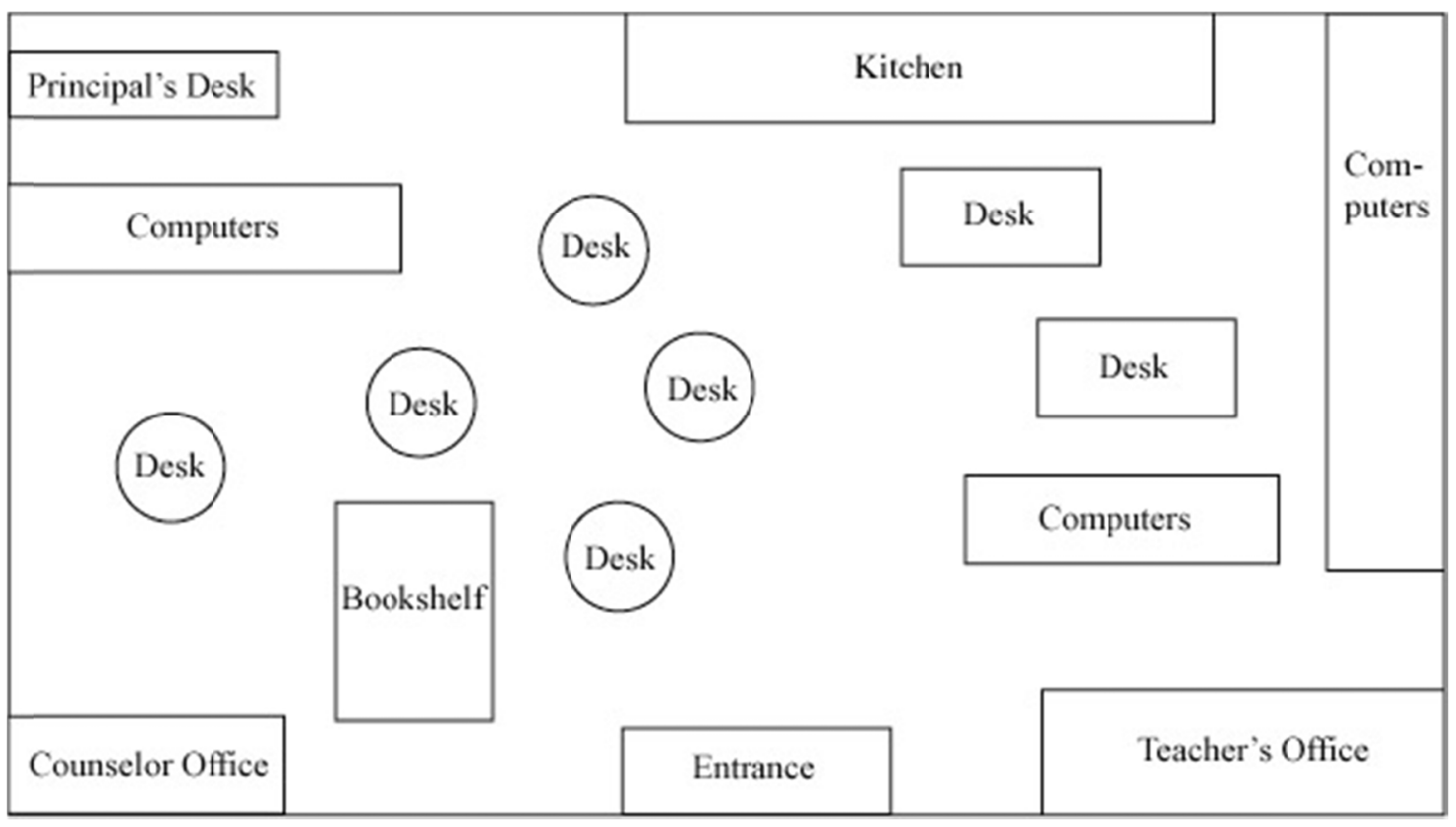

Figure 1: Diagram of Sunnydale Enrichment Institute

The EI was a one-classroom schoolhouse that had two small offices for the teachers to the side, a kitchen and a bathroom in the back, and a large classroom in the center. The large classroom was divided into a media center and a location for seminars that was mostly just desks and chairs both for individual and group work. The classroom walls, were covered with various kinds of artwork that the students had created, including a wall graffiti that had motivational messages written by students themselves. Figure 1 illustrates the Sunnydale Enrichment Institute's room layout.

At the time of the study, the EI had around 70 students and five staff members (two full-time and three part-time) who all took the role of teachers. The students would come in any time during the day that they had promised with the teachers, either morning or afternoon.

\subsection{Data Collection and Analysis}

Various data sources were collected and analyzed for understanding the school's culture of learning and the disadvantaged students' position and perspectives on the school change. Researcher observations, field notes, focus-group interviews, and individual interview data were collected, with researchers visiting the school for three to five hours every week or two.

Ten EI students, five EI staff members, and one district administrator who was involved in establishing the school participated in the study. Classroom observation data were collected during the first several weeks, focusing on values and norms of the school culture and instructional environment, along with the relationships and interactions in the school. Based on the observation field notes, we constructed semi-structured interview questions for both 
individual and focus group interviews.

The interview questions were all designed to be semi-structured, so that the participants would feel free to elaborate on questions that were more motivating to them, including perspectives on learning, school culture, and systemic change. Interviews were conducted in an informal and comfortable setting, and took place in either one of the two EI offices. Each interview included around one to three based on participant preference. Table 2 lists the study participants and their experiences in the educational system.

Table 2: Study Participants

\begin{tabular}{|c|c|c|c|}
\hline Role & Pseudonym & Year in Education & Year in School \\
\hline \multirow{11}{*}{ Students } & Jenny & Junior & 1 year \\
\hline & Samira & Senior & 3 years \\
\hline & Rick & Senior & 3 years \\
\hline & Kyle & Sophomore & 1 year \\
\hline & Eric & Senior & 2 years \\
\hline & Ayesha & Senior & Half year \\
\hline & Pat & Junior & Half year \\
\hline & Brittany & Senior & Half year \\
\hline & Kristy & Junior & 2 years \\
\hline & Sean & Senior & Half year \\
\hline & $\begin{array}{c}\text { Bob } \\
\text { (Principal) }\end{array}$ & $\begin{array}{c}25 \text { years of teaching and } \\
\text { administration }\end{array}$ & 4 years \\
\hline \multirow{4}{*}{ Staff } & $\begin{array}{c}\text { Liz } \\
\text { (Teacher) }\end{array}$ & 6 years of teaching & 3 years \\
\hline & $\begin{array}{l}\text { Susan } \\
\text { (Aide) }\end{array}$ & $\begin{array}{l}\text { Delta airlines full time } \\
\text { employee, } 4 \text { years as } \\
\text { instructional-aide }\end{array}$ & 3 years \\
\hline & $\begin{array}{c}\text { Ken } \\
\text { (Aide) }\end{array}$ & $\begin{array}{l}8 \text { years as part-time } \\
\text { instructional-aide }\end{array}$ & 1 year \\
\hline & $\begin{array}{c}\text { Pat } \\
\text { (Counselor) }\end{array}$ & $\begin{array}{c}20 \text { years of teaching and } \\
\text { administration }\end{array}$ & 3 years \\
\hline $\begin{array}{c}\text { District } \\
\text { Administrat } \\
\text { or }\end{array}$ & Greg & $\begin{array}{c}30 \text { years of teaching and } \\
\text { administration }\end{array}$ & N/A \\
\hline
\end{tabular}

The data analysis was guided by the work of Habermas (1987) and Carspecken's (1996) approach to critical inquiry and critical ethnographic methodology. All observation field notes and the transcribed interview data were analyzed with meaning field analysis and 
reconstructive horizon analysis, which aided the researchers with discourse analysis and meaning making of the field notes and interview data. The analyzed data was coded through a coding process of high-level and low-level inference coding. In addition to discourse analysis and coding, awe engaged in member-checking with all participants and peer-debriefing with colleagues in the Midwest systemic change support team. We applied systems analysis to help gain understanding of the macro-level social theories and cultures that emerged from the discourse analysis. Finally, we used strip analysis and negative case analysis methods that helped us to recognize and categorize the outliers that were identified during the coding process (Carspecken, 1996).

\section{Results and Findings}

The results fall into two major categories: school culture and improvement (research questions 1 and 2) and participation in systemic change (research question 3 and 4).

\subsection{School Culture and Improvement}

Research question 1 and 2 asked, "From disadvantaged students' perspective, what kind of school culture is needed?", and "From disadvantaged students' perspective, how can schools be improved?"

A typical day at the EI would see students and teachers being very active and humorous. You would see students walking around to get food from the kitchen, talking to teachers or friends about different topics, sitting at computers or at tables with worksheets and books, sometimes with headphones on, working either in groups or alone. Children would often be playing at the EI, as girls would often bring their children.

The institute had around 70 students and five staff members, Bob the principal, Liz the only full time teacher, and three part-time staff, Pat the counselor and Mary and Ken the instructional aides. The students would receive help from all five staff members on their schoolwork. While most students worked individually, they would naturally form a group and support each other through various forms of peer-tutoring. A teacher would also be working either with a group of students or one-on-one with a student.

The most important aspects of the culture noted by participants were learning choices and control, the relaxed environment, relationships they had built, and the atmosphere of understanding that life is bigger than school.

We need choice and control. At the EI, the students were allowed to choose among learning packets, PowerPoint projects, posters, movies and Plato [computer based learning software] to engage in their studies. Students who were working on packets usually were studying math or English, whereas others who were studying science or social studies were more likely to be engaged in PowerPoint, posters, or movie projects. Students talked about how choice and control were critical in their schoolwork, saying that the EI "doesn't hold you down and make you learn the way they want to teach you. At our school ... you can do your work in different 
ways... It's all up to you."

Samira's experience in the school was a good example of what the alternative school strived for. Samira was an 18-year-old, African American girl who had a sweet demeanor. When we started talking about her life and school, she explained to me that she had been in a juvenile correction facility for over a year due to getting into fights in the streets. She said that for years, she thought she would never graduate high school. But now, she said she had 14 credits left to finish, and that she was one of those people who knew what she wanted to be in the future: a nurse. Samira pointed out how choice and control were critical.

For me, the most important thing is that you get a lot of choice... You can work at your own pace and work on things so you actually understand what you're doing, instead of having to be done when the teacher tells you to be done.

Teachers mentioned that usually the level of learning of the students would be very low when the students started in the EI; however through the years, the students would rapidly progress. And by their senior year, they would be taking the Graduation Qualifying Exam without problems. In reality, many of the students who had given up on their hopes to finish high school had clearly developed intrinsic motivation in their education and aspirations for higher education in their interest area.

Lisa, the full time teacher, stressed how choice and control were critical in these students' learning. "As soon as you change the role of the teacher to be more of a facilitator or a project coordinator, and you're not the authority figure, suddenly all the problems go away... It's like magic."

We need a relaxed atmosphere. The students often recalled how they used to get into trouble all the time at the traditional school. One student said, "I used to get into trouble for nothing. Nothing! And teachers would always say 'what's wrong with you?" He pointed out how the EI's relaxed environment naturally encouraged him to work without getting into trouble all the time.

They [the teachers at the high school] just wanted you to get your stuff done and get out. Teachers here aren't like that... They don't get mad for talking and joking with other people... We are all like real people. It's a lot more motivating. Just having to come in every single day and sit through eight periods of class is really hard for some kids. Putting so much stress makes students to hate school ... so this more relaxed learning environment [I discuss the students' use of educational vocabulary later] really works. It takes an awful lot of stress off....

The teachers, including Ken, an instructional aid, shared the students' observations on how the behavioral problems would disappear.

I actually have been over at the high school, but they eliminated my position and reassigned me here. I really like it here. It's more open, you're able to really help and create things here, and there are no time periods to get something done in a 50-minute period... And you don't get some problems that you have at the traditional high school, like trying to make kids do 
work. They do need the freedom and less regulation. I have some kids I had over at the high school, and over there they wouldn't do anything. And now over here, they have really turned their lives around.

We need relationships and heroes. The students' also emphasized the strong need for relationships and so-called heroes in schools. Different students identified more with different staff members, but the common theme was that the students felt a strong connection with the staff. Samira talked about how at the traditional schools, she felt the teachers were distant, and would "just sit at their desks all day".

The relationships with the teachers are most important to me. The teachers show me that they care. It really makes me feel good knowing that they care about me, my life, and the things that I am going through.

Rick shared similar experiences. Like many other students in the school, Rick was working full time to support his family. He valued hard work and masculinity and described himself as one who had to really "work hard and accomplish something". Rick was not shy about telling me why he was not happy with his previous school experiences, but he was also very clear that his current school and his relationship with the staff was something different, something he could work with.

When I first came here, I thought it was going be like any other school, didn't give much crap about anything... But Mr. K really got me turned around and changed how I thought about everything. Mr. K turned everything around for me. Actually, I've been sober [from drugs] for over a year now and coming to school ... because of him.

Life is bigger than school. Students discussed how they felt that life was just "bigger" than school. Sean talked about how the EI allowed him to also focus on important non-educational aspects of his life. Sean was a shy and diligent student who the teachers regarded very highly. He had never really had problems in the traditional school but had to come to the EI as his single mother worked very long hours, and he was responsible for taking care of his three younger siblings.

I think other people [the traditional high school students] would really like our school, too... The shortness of the day is very nice for us, because some of us have to hold full-time jobs just for their family to make it, or take care of their kids... like Jamie has two little baby girls she needs to take care of... And I need to help out with work at home for my mom to be able to work.

Rick shared similar thoughts with Sean and Kyle. He felt that school should not get in the way when he needed to support his family.

It's really hard working two jobs and coming to school, you know. Over at the high school, I had to work two jobs and go to school... Now that I'm at the EI, I can work full time and still go to school. That's the best thing. I can come in and keep working on my schoolwork so I can graduate and then go work like I need to. Of course, when I started I was on drugs and things... and drinking when I first came here so it was worse then, so things were different. 
But being here... Things have really turned around for me.

Bob agreed, saying that the kids at the EI were there for various reasons, such as trouble with the law, drugs and pregnancy. "Life is not really like what you learn 'in school'. These kids need to take care of some things that most kids at the traditional high school don't have to deal with." Lisa went on to talk about how she wanted to help students see the world in a more relevant way and help them with their 'real' problems.

The kids at EI ask you when you tell them to do something, 'Why do I have to do this? What does it have to do with my life?' They need it to be meaningful to them. They have so much going on in their lives other than school; they need to know why it's worth it to do this.

Instructional aid Susan also discussed her concerns about where the US educational system was headed, taking the example of the high school's recent decision on adding more credits for graduation. "No, no, no, no. That doesn't work." She strongly felt that the system was "just trying to keep them busy", and "that's what's wrong about our education system."

\subsection{School Change}

Research question 3 and 4 asked "Are members of the alternative school involved in the district-wide change effort? How can the district-wide change effort be improved to better represent disadvantaged students?" The participants outlined how the alternative school was excluded from the school change effort despite their school culture mirroring the vision of the effort. They also discussed how they felt that they could be an important part of school change and hoped to be included in the future.

We're excluded. One of the most important principles of the Path to Success effort was to involve all stakeholder groups within the entire district, including teachers, administrators, staff, parents, community members, and students. Stakeholders, including parents from many different schools, were invited to serve on a decision-making team for the Path to Success called the Leadership Team. While the students did not actually direct the decision-making, they were also invited to work as the 'lunch group', giving them a chance to provide input on their vision of the transformed schools.

However, these participations were limited to the traditional schools, so alternative school students and their parents had virtually no involvement. All students reported that they knew of Path to Success because they had seen the 'Vision Mission Statement' mounted on the school buildings, but they did not have much understanding of it. Eric's response, 'I've heard about it, heard of it from Mr. K. Don't really know about it," was a typical one. The students all stated that neither they nor their parents had ever been involved with any Path to Success activities.

The staff of EI also knew that change efforts were going on in the district, but had limited information, and usually had that information because of other roles they had in the school district, like an employee at another building or a parent of a student, rather than as staff at EI. Lisa knew the least about the Path to Success among the five staff members. 
Well, I've only heard about the Path to Success from you [the researchers], really. I've never heard about it ever from anybody. I only saw the Path to Success Vision Mission statement on the walls. It's fine, and I certainly didn't have a problem with it. It's great trying to be reflective with the aim to serve students better, but it was somewhat generic. And I feel like EI could have been included more, and gotten some more support, too, by doing that. I just feel like ... some just basic, very basic things ... our kids are being denied. These kids don't fit in very well in the traditional setting, but because of that, do they have to be denied from these basic needs? Yeah, the Vision Mission statement is great, but is it really serving all students? Are we best serving the alternative students, with the apparent lack of resources, help, and support?

But we live it. While both the staff and students of EI felt that they weren't directly included in the Path to Success, the staff felt that the large vision of the change effort provided a positive direction for the EI's culture of learning. Both Alicia the counselor, and Bob shared how they believe that the vision of the district has provided groundwork for this type of institution of learning. Alicia emphasized how they were challenging themselves to embody the vision because the vision fit particularly well with how the EI was structured. Bob was also confident about how the EI was "living" the vision.

This alternative school has become something that is different [from what we planned in the beginning], but still I know that we live the Path to Success mission. We do live a lot of those things that we talk about in Path to Success. We really do try to live the vision... The information-age school where every single child gets attention and gets to learn at their own pace.

We can help with school change. While both the staff and students of EI felt that they weren't currently included in the Path to Success, they still were hopeful for being included in the future. Susan's thoughts were that the EI still had a fundamental connection to the Path to Success and that it would eventually be more included in the district-wide dialogue.

I feel like sometimes we are totally forgotten about over here. But the concept, at the very top, because Path to Success' goal is to get every kid educated, I also think that it is because of the Path to Success that this school is here, and these kids here get another chance... I [just] think we need a lot of people to change their way of thinking. We've got to rethink our thinking, and it's very hard. Change is hard to get the entire group on board. Some people had a harder time, and some people are very open. But that's how the world works. We need to change how we think about schools.

Lisa also talked about how she would really like to represent the EI community if she had the chance and if she were asked to be a part of the Path to Success. She commented on the importance of communication multiple times, and how she felt that the EI needed more of that with the high school.

Perhaps the most interesting feedback was from students who also wanted to give their ideas for the district change effort to improve schools for future students who had trouble in school like themselves. 
I think I would really like talking to people from schools. Just sitting down and talking about what we think and stuff like we're doing now. I can tell you a lot of stories about my friends and really talk about how schools should be more like our school here.

Ayesha shared her thoughts, suggesting how schools should "change things up". She underscored how she had some good ideas, such as different ways of preventing girls from getting into trouble compared to boys, with a focus on socializing and having fun.

They [the schools] could change it up, you know. Like school dances. They only have one school dance a year. I don't think that's enough, really. I think we should have more school dances. ... It'll make girls stay out of trouble and the streets, you know. Other than just having basketball, football, baseball and things for the boys. If they did more of those dances and things more, it would be better for girls.

Kristy concurred, adding that she would be greatly interested in sharing her voice. "I would like to help keep people off the streets and keeping them out of trouble."

The findings showed that EI members felt that they were not directly included in the Path to Success as stakeholders. Nevertheless, they had a sense of pride that the EI's work was grounded in the Path to Success, and that they were truly "living the Path to Success' vision" of the information-age school, much more than the other traditional schools.

The disconnect. Even with the yearning for inclusion and wanting to be heard, the students and staff of the EI both shared strong feelings of isolation or misunderstanding by the district and traditional high school. Many girls talked about wanting to go to prom or use the district library, and the boys would talk about how it was unfortunate that they did not have sports.

Lisa described how the feeling of isolation and misunderstanding was not limited to the students, but was also shared by her and her colleagues. And how she felt that the EI staff was looked down on, because they were teaching the students that were not wanted over at the traditional school. Bob noted how he thought that the EI was not getting enough credit for what it does and what it strives for.

When Bill [the superintendent] hired me, he said, 'Bob, I want you to create an alternative school that is totally different than any other alternative school.' We did that. I know that we live the mission of the school district. But it's defeating when our colleagues look at us and question if we are doing a good job here.

The EI members felt that the only solution to the current state of alienation and isolation was to improve communication and have other teachers and administrators come to the EI and see what is going on in the school.

For us to really change the perception towards us, I feel a strong need for communication with the high school and other schools. I don't know if they want to come, but if they come and observe, they'll see.

A district administrator, Director of Special Projects, Greg, shared his perspective on the EI's isolation within the school district as a whole: “... it was never supposed to be that way, 
where you're excluding kids. You're supposed to be encouraging them to become successful rather than isolating them." It was clear that Greg shared concerns with the staff that the EI was excluded and alienated from the school district. When we asked if he thought there might be a chance to put a committee together for the EI and work on this problem, he shook his head, saying that he had doubts that it would happen in the near future. Even though Greg was concerned about the marginalized community, he could not see the district administration coming together to make things change for the EI. That was a somewhat different perspective from what the students and staff of the EI held about the EI's future.

\section{Discussion}

Perhaps one of the most interesting aspects of the students at the EI was how they frequently engaged in a dialogue about teaching and learning, using professional educational vocabulary with the teachers. During our discussions, they would talk about how their "learning environment" differed from the traditional schools, and how they believed the "graduation rates" would increase if the schools were able to change to be more flexible. It was clear that they were encouraged to be reflective about their learning process and were discussing the reasons behind learning decisions the teachers and students together had made as collaborators. The discussions about their learning were helping the students to take ownership over their schoolwork and to become more active participants in their school experiences overall, such as building intimate friendships, engaging in recreational games, decorating the classroom, or cooking for their peers. These open and inviting dialogues with disadvantaged students about learning and teaching may be a very important method for engaging those students and facilitating their success in school.

The culture of dialogue not only facilitated ownership and agency of learning for these students, but also created stronger relationships with their teachers, so-called heroes (Lawrence-Lightfoot, 1983), and supported the school community to have a coherent vision with clear values (Johnston, 1992). The teachers all took on a drastically different role in the lives and learning process of these students compared to traditional teachers, viewing themselves as the guides, facilitators, fathers, and mothers of the students, and even grandparents of the students' children. And students portrayed their teacher as a person "who cares about me", "who makes me feel good", "who turned my life around", and even as someone who is "my savior".

EI students were also continuously engaging in an active, self-learning, planning process. This process was clearly enhancing motivation by placing greater responsibility and ownership on the students (Schlechty, 2002). They had learned to set and meet deadlines on their own, rather than being micro managed to do a certain amount of work every day, which is very similar to the literature on learner-centered instruction, personalized learning, and differentiated learning that calls for the creation of personalized environments that support self-regulated learners who take more control of their own learning (Alexander \& Murphy, 1993; Bransford, Brown \& Cocking, 2003; Lambert \& McCombs, 1998; McCombs \& 
Whisler, 1997; Reigeluth, 1994; Tomlinson, 2003).

Another very important perspective of this study is the need for disadvantaged students, parents, and their teachers, to have their voices heard and to be given an active role in educational change processes. By not including the EI community in the change effort and by not being aware of what the EI was doing as a learning community, change leaders missed a powerful opportunity to receive valuable input in the change process and instead continued the culture of isolation that exists within the traditional system.

As discussed earlier, EI students were not involved in any way in the district's change effort. However, they exhibited an enthusiasm for sharing their perspectives and lending their voices to the change effort. As students who had largely failed in the existing educational system and were now experiencing success in a more learner-centered environment, they felt that they had much to share to help other students who were having problems. While the EI was created to help these students, the students and teachers of the school largely felt that the EI was being used to get rid of the problem students, and this culture of isolation and disrespect in the district made it a greater challenge for these students' voices to be heard.

In addition, the study shows that there was a clear need for teachers of disadvantaged students to be involved in change efforts, as staff were experiencing patterns of isolation and resistance from the district as well. As stakeholders in the district who identified strongly with the district's vision for a new way of schooling, the teachers and staff felt proud that they were "living the mission" but were disappointed that their efforts were largely unnoticed or even considered with suspicion. These feelings of isolation and resistance served as obstacles to having these resourceful teachers participate as leaders in the change effort. Because the EI teachers and staff members were largely responsible for dealing with all of the students in the district who had been unable to succeed in the traditional learning environment, they were likely the most experienced stakeholders in implementing the kind of learner-centered approaches for which the district's vision statement called. For the alternative school members to be uninvolved in the change effort and furthermore feel isolated from the rest of the district is a clear obstacle and one that should be avoided in future systemic change efforts.

In addition to the lack of involvement of alternative school students and staff in the systemic change effort, parents of the disadvantaged students also were completely uninvolved in the change effort. A recurring theme in the data was that for many of the disadvantaged students, there were more important things in life than school. The fact that some students had come to the EI because they were unable to meet their outside responsibilities, such as working full time to support their family, in the traditional school setting illustrates how the parents of these disadvantaged students often faced significant challenges in life and educating their children, and therefore had considerable obstacles which prevented them from actively sharing their viewpoints and participating in any school activities. Many of these students' parents often relied on their children to provide for the family by working or taking care of their siblings. Special effort needs to be made to help these parents be involved in the process. This could include monetary support for the hours they provide in the effort, childcare and 
transportation services, as well as scheduling meeting times for a variety of work schedules. These parents, much like their children, likely have the perspective that the district does not truly wish to hear their point of view; it is important that significant effort be placed in encouraging them to be involved and share their experiences and viewpoints.

The findings of this study reinforce the importance of communication across a district so that teachers and staff are aware of the successes and lessons learned by their peers, and a true collaborative learning community can be created which brings a variety of viewpoints fully representing all stakeholders to the change process (Duffy, 2006; Jenlink et al., 1998).

\section{Study Limitations and Future Research}

While implications and recommendations might be drawn from this study that could inform and benefit other district-wide systemic educational change efforts, this study only presents one case of an alternative school's culture and perspective on school change. Future studies should explore other alternative schools or programs in public school districts in the United States for a better understanding of the kinds of influences or interrelationships that educational change efforts have with disadvantaged populations.

This study also was not able to incorporate the voices of the parents of disadvantaged students. We believe in expanding research to the parents, to understand their perspectives and visions for their children's schooling. Understanding a more holistic picture of diverse perspectives on school change will be a valuable input for systemic educational change efforts to draw from.

Finally, in addition to understanding the full picture of the disadvantaged and marginalized student community's needs and vision of schooling, it is important to explore what kinds of support systems and policies are needed to obtain meaningful contributions from these members. This study indicated that these students and teachers wanted to be included as respected members of the educational change effort. For example, it would be valuable to compare what kinds of communication methods or resources are most effective in bringing these members to be more active in the change process. These effective methods and resources will likely be different for students, teachers, and parents.

These additional research findings will be invaluable in advancing theory and guidelines for engaging the disadvantaged and marginalized communities in systemic change.

\section{Conclusion}

This study examined the culture of learning and the perspectives on school change of a marginalized learning community by exploring a disadvantaged, isolated, alternative school community in a US public school district that was going through an educational change process. Systemic educational change encourages the inclusion of all stakeholder groups, and this study indicates that, much like creating mindset change, true inclusion of all stakeholder 
groups, particularly traditionally alienated or non-mainstream groups such as the teachers and staff of the alternative school, is very challenging but critical to the success of a change effort.

The findings of this study indicate that systemic educational change efforts could be enriched with the input and experiences of these disadvantaged students and their teachers. Communication, attention to detail, and full understanding of the state of the existing system, including its underlying cultures and habits, are important in order to truly involve and empower all stakeholder groups. Further research in systemic educational change and school culture for disadvantaged students is needed in order to reflect on more actionable support, solutions and policies where these disadvantaged and marginalized students and their teachers will become more active agents and beneficiaries of change in our educational system as a whole.

\section{References}

Ackoff, R. L. (1981). Creating the corporate future: Plan or be planned for. New York: Wiley.

Alexander, P. A., \& Murphy, P. K. (1993). The research base for APA's learner-centered psychological principals, taking research on learning seriously: Implications for teacher education. Paper presented at the Annual Meeting of the American Psychological Association, New Orleans.

Anyon, J. (1981). Social Class and School Knowledge. Curriculum Inquiry, 11(1), 1-42. http://dx.doi.org/10.2307/1179509

Apple, M. (1979). Ideology and Curriculum. London: Routledge and Kegan Paul.

Banathy, B. (1991). Systems design of education: A journey to create the future. Englewood Cliffs, N.J.: Educational Technology Publications.

Battino, W., \& Clem, J. (2006). Systemic Changes in the Chugach School District. Techtrends, 50(2), 51-52.

Bernstein, B. (1975). Class, Codes and Control (Vol. 3). London: Routledge and Kegan Paul. .

Bertalanffy, L. (1968). General systems theory, foundations, development, applications. New York: Braziller.

Bransford, J. D., Brown, A. L., \& Cocking, R. R. (Eds.). (2003). How people learn. Washington, D.C.: National Academy Press.

Brown, L. M., \& Gilligan, C. (1992). Meeting at the crossroads women's psychology and girls' development. Cambridge, Mass.: Harvard University Press.

Caine, R. N. (2006). Systemic changes in public schools through brain-based learning. 
Techtrends, 50(2), 52-53.

Carr-Chellman, A., Beabout, B., Almeida, L., Gursoy, H. (2009) Idealized visions from behind bars: Prisoners' perspectives on school change. International Journal of Educational Reform. 18(2), 155-172.

Carspecken, P. F. (1996). Critical ethnography in educational research: A theoretical and practical guide. New York: Routledge.

Checkland, P. (1984). Systems thinking, systems practice (Reprinted with corrections February 1984 ed.). New York: John Wiley \& Sons.

Cohen, J., \& Fung, A. (2004) Radical democracy. Swiss Journal of Political Science, 10(4). http://dx.doi.org/10.2307/25096843

Cox, T. (Ed.). (2000). Combating educational disadvantage: Meeting the needs of vulnerable children. London: Falmer Press.

Day, C., Veen, D. v., \& Walraven, G. (1997). Children and youth at risk and urban education research, policy and practice. Leuven, Belgium: Garant.

Duffy, F. M. (2006). Step-up-to-excellence: A change navigation protocol for transforming school systems. Retrieved October 29, 2006 from http://cnx.org/content/m13656/latest/

Fincher, R., \& Saunders, P. (Eds.). (2001). Creating unequal futures? Rethinking poverty, inequality and disadvantage. Sydney: Allen \& Unwin.

Flood, R. L., \& Jackson, M. C. (1991). Creative problem solving - Total systems intervention. New York: John Wiley and Sons.

Furman, G. (2004). Moral leadership and the ethic of community. Values and ethics in educational administration, 2(1), 1-8.

Giroux, H. A. (Ed.). (1991). Postmodernism, feminism, and cultural politics: Redrawing educational boundaries. Albany: State University of New York Press.

Habermas, J. (1987). The theory of communicative action: Lifeworld and system: A critique of functional reason (T. McCarthy, Trans.). Boston: Beacon Press.

Hammer, M., \& Champy, J. (1993). Reengineering the corporation: A manifesto for business revolution. New York: Harper Business.

Hammer, M., \& Champy, J. (2003). Reengineering the corporation : a manifesto for business revolution (1st HarperBusiness Essentials pbk. ed.). New York: HarperBusiness Essentials.

Hargis, C. H. (2006). Teaching low achieving and disadvantaged students. Third Edition. Springfield, IL: Charles C. Thomas.

Heath, S. B. (1983). Ways with words language, life, and work in communities and 
classrooms. Cambridge [Cambridgeshire]; New York: Cambridge University Press.

Indiana Department of Education (2010). School district data. Retrieved December, 2010 from http://www.doe.in.gov

Jenlink, P. M., Reigeluth, C. M., Carr, A. A., \& Nelson, L. M. (1998). Guidelines for facilitating systemic change in school districts. Systems Research and Behavioral Science, 15(3), 217-233.

Johnston, J. H. (1992). Climate and culture as mediators of school values and collaborative behavior. In J. L. Irvin (Ed.), Transforming middle level education perspectives and possibilities. Boston: Allyn and Bacon.

Lambert, N. M., \& McCombs, B. (Eds.). (1998). How students learn: Reforming schools through learner-centered education. Washington, DC: American Psychological Association.

Lareau, A., \& Horvat, E. M. (1999). Moments of social inclusion and exclusion: Race, class, gender, and cultural capital in family-school relationships. Sociology of Education, 67(January), 37-53.

Lawrence-Lightfoot, S. (1983). The good high school portraits of character and culture. New York: Basic Books.

McCombs, B., \& Whisler, J. S. (1997). The learner-centered classroom and school: Strategies for increasing student motivation and achievement. San Francisco: Jossey-Bass Publishers.

Mehan, H., \& Griffin, P. (1980). Socialization: The View from Classroom Interactions. Social Inquiry, 50(1), 357-398.

Natriello, G., McDill, E. L., \& Pallas, A. M. (1990). Schooling disadvantaged children racing against catastrophe. New York: Teachers College Press, Teachers College, Columbia University.

Oakes, J. (1992). Can tracking research inform practice? Technical, normative, and political $\begin{array}{llll}\text { considerations. } \quad \text { Educational } & \text { 21(4), } 21 .\end{array}$ http://dx.doi.org/10.2307/1177206

Reigeluth, C. M. (1994). The imperative for systemic change. In C. M. Reigeluth \& R. J. Garfinkle (Eds.), Systemic change in education (pp. 3-11). Englewood Cliffs, NJ: Educational Technology Publications.

Squire, K. D., \& Reigeluth, C. M. (2000). The many faces of systemic change. Educational Horizons, 78(3), 145-154.

Schlechty, P. C. (2002). Working on the work: An action plan for teachers, principals, and superintendents (1st ed.). San Francisco: Jossey-Bass.

Schorr, L. B., \& Schorr, D. (1988). Within our reach breaking the cycle of disadvantage. 
New York: Anchor Press/Doubleday.

Senge, P. M. (1990). The fifth discipline: The art and practice of the learning organization (1st ed.). New York: Doubleday.

Senge, P. M. (2000). Schools that learn: A fifth discipline fieldbook for educators, parents, and everyone who cares about education (1st ed.). New York: Doubleday.

Slavin, R. (1990). Achievement effects of ability grouping in secondary schools: A best-evidence synthesis. Review of Educational Research, 60(3), 471-499. http://dx.doi.org/10.3102/00346543060003471

Snyder, I., Angus, L., \& Sutherland-Smith, W. (2002). Building equitable literate futures: Home and school computer-mediated literacy practices and disadvantage. Cambridge Journal of Education, 32(3), 367-383. http://dx.doi.org/10.1080/0305764022000024212

Tomlinson, C. A. (2003). Fulfilling the promise of the differentiated classroom: Strategies and tools for responsive teaching. Alexandria: Association for Supervision and Curriculum Development.

Wilcox, K. (1982). Differential Socialization in the Class- room: Implications for Equal Opportunity. In G. Spindler (Ed.), Doing the Ethnography of Schooling (pp. 269-309). New York: Holt, Rinehart and Winston.

Willis, P. E. (1981). Learning to labor how working class kids get working class jobs. New York: Columbia University Press.

\section{Copyright Disclaimer}

Copyright reserved by the author(s).

This article is an open-access article distributed under the terms and conditions of the Creative Commons Attribution license (http://creativecommons.org/licenses/by/3.0/). 